\title{
Comparison of an elemental with a hydrolysed whey formula in intolerance to cows' milk
}

\author{
C M McLeish, A MacDonald, I W Booth
}

\begin{abstract}
In a double blind study, 40 infants with cows' milk intolerance of various causes were randomised to receive a nutritionally complete formula in which nitrogen was supplied either as whey hydrolysate or amino acids. The median age of infants was 10 weeks (range 36 weeks' gestation to 108 weeks' postnatal age). After a median follow up period of 25 weeks there was no significant difference in dietary intake between the formulas. Twenty four weeks after entry, weight and weight for length improved equally on both formulas. Plasma albumin improved significantly on the hydrolysed whey formula but not in the amino acid group. Both milks were palatable and normal intakes of formula were maintained. Biochemical and haematological indices remained within normal limits. There was no difference in stool frequency and vomiting between the two formulas. Two infants developed a probable allergic colitis while receiving hydrolysed whey. Amino acid formula may have a role in the management of atopic infants with severe cows' milk intolerance who have already reacted to whey or casein hydrolysate formula.

(Arch Dis Child 1995; 73: 211-215)
\end{abstract}

Keywords: cows' milk intolerance, whey hydrolysate, elemental formula.

The number of specialised formulas for the treatment of cows' milk intolerance has increased markedly, but few studies have compared the efficacy of different nitrogen sources, particularly with respect to feed tolerance, palatability, and growth. Each nitrogen source has inherent merits and disadvantages. Formulas based on casein hydrolysates have been widely used for over 40 years. In these, nitrogen is present as peptides and free amino acids. They have been shown to be non-sensitising in the guinea pig $^{1}$ and reports of adverse clinical reactions are rare. Unfortunately their unpalatability and high cost are disadvantages. The relatively high carbohydrate concentration $(9 \mathrm{~g} / 100 \mathrm{ml})$ in some formulas may lead to carbohydrate intolerance, particularly following neonatal gastrointestinal surgery. In contrast, whey hydrolysates are relatively new. They usually have a lower carbohydrate $(7 \mathrm{~g} /$ $100 \mathrm{ml}$ ) concentration, and are arguably more palatable than casein hydrolysates. There have already been several reports indicating intolerance to whey hydrolysates in vivo and vitro ${ }^{2} 3$ as well as fatal and severe reactions in the guinea pig, but it is too early to tell whether they are truly more sensitising. ${ }^{4}$

Special formulas based on amino acids have a higher osmolality than hydrolysed protein formulas and there is evidence that free amino acids are more slowly absorbed than peptides from a hydrolysed protein formula. ${ }^{5-7}$ Moreover, feeds containing only free amino acids as their nitrogen source are generally unpalatable and expensive. However, allergic reactions to pure free amino acids are very unlikely, even in children with severe cows' milk protein intolerance.

To date there has been no direct comparison of feed tolerance, palatability, and growth in children receiving formulas containing nitrogen derived from hydrolysed protein or from a free amino acid nitrogen source. We have therefore conducted a randomised, double blind study in patients with varying forms of intolerance to cows' milk formula. We compared two nutritionally complete formulas in which only the nitrogen sources differed: a whey hydrolysate and an amino acid based feed.

\section{Methods}

\section{SUBJECTS}

Forty infants and children with a median age of 10 weeks (range 36 weeks' gestation to 108 weeks' postnatal age) were recruited (table 1). The criteria for inclusion in the study were the presence of persistent diarrhoea while receiving a cows' milk formula; persistent postgastroenteritis diarrhoea; or diarrhoea following neonatal gastrointestinal surgery (table 1). The diagnosis of cows' milk intolerance was based on the onset of diarrhoea and failure to thrive, sometimes in conjunction with a rash, following the introduction of cows' milk into the diet. A family history of atopy was almost invariable and an eosinophilia was common. Symptoms settled promptly following

Table 1 Age, sex, and clinical disorder at entry

\begin{tabular}{lll}
\hline & $\begin{array}{c}\text { Amino acid } \\
\text { formula } \\
(n=20)\end{array}$ & $\begin{array}{l}\text { Hydrolysed } \\
\text { whey formula } \\
(n=21)\end{array}$ \\
\hline Age (weeks) & & \\
Median & $8 \cdot 5$ & 15 \\
Range & $36 / 40-108$ & $39 / 40-81$ \\
Sex (m/f) & $8 / 12$ & $7 / 14$ \\
Clinical disorder & 7 & 9 \\
Cows' milk protein intolerance & 7 & 9 \\
Persistent post-gastroenteritis & 6 & 6 \\
$\quad$ diarrhoea & 6 & 1 \\
Diarrhoea following neonatal gastrointestinal surgery: & 1 & 2 \\
Ileal atresia & 1 & 2 \\
Necrotising enterocolitis & 2 & 1 \\
Vestibular/imperforate anus & 2 & 0 \\
Gastroschisis & 1 & \\
Oesophageal atresia & 1 & \\
\hline
\end{tabular}

The Children's C M McLeish

Institute of Child Birmingham I W Booth 
withdrawal of cows' milk. Jejunal biopsy was not routinely performed and Goldman criteria ${ }^{8}$ were not applied. Patients with chronic extraintestinal disease likely to affect growth were excluded from the study. Ethics approval for the study was obtained from the committee on medical ethics of South Birmingham Health Authority.

A total of 40 infants in the study gave a probability of detecting a difference of $900 \mathrm{~g}$ between groups at the $5 \%$ significance level, with a power of $80 \%$.

\section{RANDOMISATION AND FOLLOW UP}

After informed parental consent, subjects were randomised in blocks of four to receive either the amino acid (AA) or hydrolysed whey (HW) formula. Nineteen subjects received the AA formula and 21 the HW formula. The subjects received the assigned formula either as a sole source of nutrition or in conjunction with milk-free solids for either six months or until they ceased to require a milk-free formula, whichever was shorter. The parents and principal investigator were blind to the study feed being taken by the subjects.

Twenty nine subjects completed the study, 16 on the AA formula and 13 on the HW formula. The median (range) length of follow up was 25 (12-28) weeks for the AA formula and $24(13-28)$ weeks for the HW formula. Only one subject in each group received the formula for less than six months.

\section{ANTHROPOMETRY}

Anthropometric data were collected fortnightly by the same observer (CMcL). Nude weight to the nearest $0.01 \mathrm{~kg}$ was measured using portable electronic scales (Seca Model 724). Length was measured to the nearest $0.1 \mathrm{~cm}$ using a Harpenden stadiometer. Head circumference and mid-upper arm circumference (MUAC) were measured to the nearest $0.1 \mathrm{~cm}$ using a paper tape measure. Standard deviation (z) scores for weight for age, length for age, and weight for length were determined using NCHS reference standards. ${ }^{9}$ MUAC measurements were expressed as percentages of the expected value for age and sex. ${ }^{10}$

Table 2 Nutritional composition of the amino acid and hydrolysed whey formulas

\begin{tabular}{lll}
\hline & Analysis per $100 \mathrm{ml}$ & \\
\cline { 2 - 3 } & Amino acid formula & Hydrolysed whey formula \\
\hline Protein & $1 \cdot 60$ & $1 \cdot 60$ \\
Equivalent $(\mathrm{g})(\mathrm{N} \times 6 \cdot 38)$ & Amino acids & Hydrolysed whey \\
Carbohydrate (g) & $7 \cdot 80$ & $7 \cdot 80$ \\
& Maltodextrin & Maltodextrin \\
& Glucose syrup solids & Glucose syrup solids \\
& Modified starch from & Modified starch from \\
hat (g) & hydrolysed maize starch & hydrolysed maize starch \\
& $3 \cdot 5$ & $3 \cdot 5$ \\
& Ground nut & Ground nut \\
Energy & Palm kernel & Palm kernel \\
kcal & Palm oil & Palm oil \\
kJ & 70 & 69 \\
\hline
\end{tabular}

\section{Biochemical and haematological investigations}

Plasma electrolytes and albumin and a full blood count were estimated from capillary samples at entry and at eight week intervals throughout the study. Urinary electrolytes were estimated at the same times.

\section{FORMULA INTAKE AND WEANING}

Parents were instructed to document prospectively the number of separate feeds and the volume of AA or HW formula taken during the study. Solids were introduced at between 3 and 6 months. While on the AA or HW formula all babies or young children were maintained on a diet free of cows' milk and all milk-containing foods. The parents were instructed to record the intake of solids using household measurements. For weaning solids the amount was usually described in teaspoons.

In subjects under the age of 9 months, the intake of solids was recorded daily in a diary. In those over 9 months, a three day food diary was completed monthly. The records and diaries were then checked with the parents by one of us (CMcL). Nutritional analysis of the total intake was calculated using the Microdiet computer program based on McCance and Widdowson's The Composition of Foods. ${ }^{11}$ Information on the nutritional composition of baby foods and the HW and AA formula were supplied by the manufacturers and added to the database. The energy and nutrient intakes were compared with the estimated average requirement for energy (EAR) and dietary reference values (DRV). ${ }^{12}$

The number of vomits and stool frequency and consistency were recorded daily by the parents in a diary.

\section{COMPOSITION OF THE AMINO ACID AND}

HYDROLYSED WHEY FORMULA

Both feeds were nutritionally complete and satisfied the recommendations for the nutritional composition of artificial formulas. ${ }^{13}$ The source of major nutrients and the basic nutritional analysis of the two formulas is given in table 2 . With the exception of the nitrogen source, the composition of the two formulas was virtually identical. Only the osmolality and sodium content of the feeds varied slightly. The osmolality of the AA and HW formulas was 320 and $190 \mathrm{mOsmol} / \mathrm{kg}$ $\mathrm{H}_{2} \mathrm{O}$ respectively. The sodium content per $100 \mathrm{ml}$ of the AA and HW formulas was 0.78 $\mathrm{mmol}(18 \mathrm{mg}$ ) and $1.22(28 \mathrm{mg}) \mathrm{mmol}$ respectively.

\section{STATISTICAL ANALYSES}

For growth data, unpaired $t$ tests were used to compare differences between the two groups and paired $t$ tests and $\chi^{2}$ tests for trend were used to compare differences within the same group. Mann-Whitney $U$ tests were used to compare differences of nutritional intake between the two groups. 
Table 3 Mean (SD) z scores for subjects who completed study

\begin{tabular}{|c|c|c|c|c|c|c|}
\hline & \multicolumn{3}{|c|}{ Amino acid formula ( $n=16$ ) (weeks) } & \multicolumn{3}{|c|}{ Hydrolysed whey formula ( $n=13$ ) (weeks) } \\
\hline & 0 & 12 & 24 & 0 & 12 & 24 \\
\hline $\begin{array}{l}\text { Weight for age } \\
\text { Mean } \\
\text { (SD) } \\
\text { (CI) }\end{array}$ & $\begin{array}{l}-0.89 \\
(0.98) \\
(-1.41 \text { to }-0.37)\end{array}$ & $\begin{array}{l}-0.76 \\
(1.01) \\
(-1.29 \text { to }-0.21)\end{array}$ & $\begin{array}{l}-0.68 \\
(0.90) \\
(-1 \cdot 15 \text { to }-0.20)\end{array}$ & $\begin{array}{l}-1.21 \\
(0.89) \\
(-1.74 \text { to }-0.67)\end{array}$ & $\begin{array}{l}-1 \cdot 16 \\
(0.80) \\
(-1.63 \text { to }-0.68)\end{array}$ & $\begin{array}{l}-1.16 \\
(0.80) \\
(-1.65 \text { to }-0.67)\end{array}$ \\
\hline $\begin{array}{l}\text { Length for age } \\
\text { Mean } \\
\text { (SD) } \\
\text { (CI) }\end{array}$ & $\begin{array}{l}-0.37 \\
(0.94) \\
(-0.87 \text { to } 0.13)\end{array}$ & $\begin{array}{l}-0.40 \\
(1.02) \\
(-0.94 \text { to } 0.14)\end{array}$ & $\begin{array}{l}-0.42 \\
(0.83) \\
(-0.86 \text { to } 0.03)\end{array}$ & $\begin{array}{l}-0.41 \\
(1.02) \\
(-1.02 \text { to } 0.20)\end{array}$ & $\begin{array}{l}-0.71 \\
(0.87) \\
(-1.23 \text { to } 0.18)\end{array}$ & $\begin{array}{l}-0.74 \\
(0.78) \\
(-1.2 \text { to }-0.27)\end{array}$ \\
\hline $\begin{array}{l}\text { Weight for leng } \\
\text { Mean } \\
\text { (SD) } \\
\text { (CI) }\end{array}$ & $\begin{array}{l}\text { th } \\
-0.82 \\
(0.86) \\
(-1.27 \text { to }-0.36)\end{array}$ & $\begin{array}{l}-0.51 \\
(1.01) \\
(-1.04 \text { to } 0.03)\end{array}$ & $\begin{array}{l}-0.43 \\
(1.0) \\
(-0.96 \text { to } 0.10)\end{array}$ & $\begin{array}{l}-1.22 \\
(0.83) \\
(-1.73 \text { to }-0.72)\end{array}$ & $\begin{array}{l}-0.75 \\
(0.84) \\
(-1.26 \text { to }-0.24)\end{array}$ & $\begin{array}{l}-0.73 \\
(0.75) \\
(-1.18 \text { to }-0.28)\end{array}$ \\
\hline $\begin{array}{l}\text { Mid-upper arm } \\
\text { Median } \\
\text { Range }\end{array}$ & $\begin{array}{l}\text { circumference }(\% \text { of } \\
95.5 \\
(80-107)\end{array}$ & $\begin{array}{l}\text { dard) } \\
99 \\
(78-109)\end{array}$ & $\begin{array}{l}98 \\
(79-100)\end{array}$ & $\begin{array}{l}87 \\
(77-100)\end{array}$ & $\begin{array}{l}87 \\
(77-107)\end{array}$ & $\begin{array}{l}92 \\
(74-107)\end{array}$ \\
\hline
\end{tabular}

\section{Results}

SUBJECTS WITHDRAWN FROM THE STUDY

Four subjects on the AA formula were withdrawn from the study, including two subjects (aged 8 weeks and 2 years respectively) who refused to drink the formula and one who required an ileal resection following necrotising enterocolitis.

Seven subjects on HW formula were withdrawn. Two subjects had incomplete data. One infant with cows' milk intolerance and bladder extrophy had frequent hospital admissions with gastroenteritis and underwent surgery for repair of inguinal hernia and closure of bladder extrophy, so we were unable to interpret his growth and biochemical data. Two infants who had neonatal gastrointestinal surgery developed carbohydrate intolerance. Two infants developed a probable allergic colitis: one with cows' milk intolerance had bloody stools after 24 hours on the HW formula, which resolved rapidly on starting a casein hydrolysate formula; the other infant developed loose frequently bloody stools two weeks after the full introduction of HW feeds following resection of the terminal ileum for subacute necrotising enterocolitis. A rectal biopsy showed a mild mucosal infiltrate comprising mainly eosinophils and consistent with allergic colitis. The symptoms resolved on a modular feed based on comminuted chicken (Cow and Gate).

\section{GROWTH}

Both groups of patients were undernourished at the start of the study. There were no significant differences in weight for age, length for age, and weight for length at the start of the study between the two groups or between these and the subjects withdrawn from the study (table 3).
Although there was an increase in weight for length within the HW group $(p<0.05)$ and not within the AA group, there was no significant difference between the two groups. Weight for age improved in both groups, but this improvement did not reach significance. There was no difference in weight or length between the groups at 24 months. There was also no difference in MUAC associated with the improvement in weight for length, and no other significant trend in any nutritional variable during the study.

BIOCHEMICAL AND HAEMATOLOGICAL RESULTS At entry and throughout the study, haemoglobin and plasma albumin, sodium, and potassium were within normal reference ranges on both feeds. Plasma albumin concentration in the patients on the HW formula increased significantly from a median value of $35 \mathrm{~g} / \mathrm{l}$ at the start of the study to $41 \mathrm{~g} / \mathrm{l}$ at the end of the study $(p<0.05)$. There was no significant change in plasma albumin for the AA formula, with a median value of $37 \mathrm{~g} / 1$ at the start of the study and $38 \mathrm{~g} / \mathrm{l}$ at the end of the study.

\section{DIETARY INTAKE}

There were no significant differences between formula and total energy intake at the start, 12 weeks and completion of the study between the two groups (table 4). Although introduction of weaning solids did reduce the intake of both study feeds, this was by the amount expected for normal infant feeding.

Before the study, six subjects who had undergone gastrointestinal or cardiac surgery were receiving additional energy supplements in their feeds in the form of added glucose polymer (Maxijul; Scientific Hospital

Table 4 Milk and total energy intake at entry, 12 weeks, and completion

\begin{tabular}{|c|c|c|c|c|c|c|c|}
\hline & & \multicolumn{2}{|l|}{ At entry } & \multicolumn{2}{|l|}{12 Weeks } & \multicolumn{2}{|l|}{ At completion } \\
\hline & & $A A$ & $H W$ & $A A$ & $H W$ & $A A$ & $H W$ \\
\hline $\begin{array}{l}\text { Formula only } \\
\text { Milk intake }(\mathrm{ml} / \mathrm{kg} / \mathrm{d}) \\
\text { Energy intake }(\% \mathrm{EAR})\end{array}$ & $\begin{array}{l}\text { Median } \\
\text { Median }\end{array}$ & $\begin{array}{l}\mathrm{n}=9 \\
177(77-311) \\
97(48-139)\end{array}$ & $\begin{array}{l}n=6 \\
167(142-206) \\
100(92-113)\end{array}$ & $\begin{array}{l}- \\
- \\
-\end{array}$ & $\begin{array}{l}- \\
-\end{array}$ & $\begin{array}{l}- \\
- \\
-\end{array}$ & $\begin{array}{l}- \\
- \\
-\end{array}$ \\
\hline $\begin{array}{l}\text { Formula and solids } \\
\text { Milk intake }(\mathrm{ml} / \mathrm{kg} / \mathrm{d}) \\
\text { Contribution of milk to energy intake (\%) } \\
\text { Energy intake (\% EAR) }\end{array}$ & $\begin{array}{l}\text { Median } \\
\text { Median } \\
\text { Median }\end{array}$ & $\begin{array}{l}n=6 \\
87(40-150) \\
120(102-152)\end{array}$ & $\begin{array}{l}\mathrm{n}=7 \\
90(29-169)\end{array}$ & $\begin{array}{l}\mathrm{n}=14 \\
138(40-189) \\
73(23-100) \\
112(77-148)\end{array}$ & $\begin{array}{l}\mathrm{n}=11 \\
93(39-163) \\
62(19-98) \\
106(72-138)\end{array}$ & $\begin{array}{l}\mathrm{n}=15 \\
89(28-124) \\
57(17-76) \\
113(73-141)\end{array}$ & $\begin{array}{l}\mathrm{n}=11 \\
79(20-122) \\
53 \cdot 5(8-76) \\
102(69-140)\end{array}$ \\
\hline
\end{tabular}

$\mathrm{AA}=$ amino acids, $\mathrm{HW}=$ hydrolysed whey, $\mathrm{EAR}=$ estimated average requirement. 
Supplies) and long chain fat emulsion (Calogen; Scientific Hospital Supplies) to provide a formula containing $93 \mathrm{kcal} / 100 \mathrm{ml}$. These additional energy supplements were added to the study feeds in the same energy density (two on the AA formula and four on the HW) for part of the study. Increasing the energy density of the formulas did not appear to reduce the actual volume of formula consumed.

FEED TOLERANCE IN THE SUBJECTS

COMPLETING THE STUDY

There was no significant difference in daily stool frequency (1.8 and 1.4) and number of vomits $(0 \cdot 1$ per day) between the AA and $\mathrm{HW}$ formula.

\section{Discussion}

To our knowledge, this is the first published double blind study to compare amino acids with hydrolysed whey protein as the nitrogen source in otherwise nutritionally identical formulas designed for infants with cows' milk intolerance. Nutritional indices increased equally in both groups. Approximately $30 \%$ of infants in either group were recovering from neonatal surgery, and both groups had low weight $\mathrm{z}$ scores at the beginning of the trial. This may have affected nutritional requirements and final nutritional outcome. Both formulas were well tolerated and there was no significant difference in stool frequency, number of vomits, or feed intake between the two groups.

Whey hydrolysate formulas have been successfully used in the treatment of patients with gastrointestinal intolerance. Taylor et al ${ }^{14}$ gave a hydrolysed whey protein (Pepti-Junior; Cow and Gate) to a group of 17 infants with complex gastrointestinal intolerances and observed no adverse reaction to the formula. WalkerSmith et $a l^{15}$ evaluated a casein hydrolysate (Pregestimil; Mead Johnson) and a whey hydrolysate (Alfare; Nestlé) in a group of 18 children with cows' milk sensitive enteropathy. Weight gain, and the improvement in small intestinal morphology was better in the infants given the whey hydrolysate formula. There is only one published study which challenged 28 children who had cows' milk protein intolerance with an amino acid infant formula (Neocate; Scientific Hospital Supplies) and no child had a clinical reaction to this. ${ }^{16}$

Reports have noted the unpalatability of hydrolysed protein ${ }^{17}$ or amino acid based formula ${ }^{16}$ and the difficulty in persuading older infants to drink sufficient volumes of either type of formula in order to meet their nutritional requirements. Comparisons of fluid intake on the two formulas studied showed that they both satisfied fluid and energy requirements and the introduction of solids did not severely decrease the volume of either formula consumed. Only two infants refused to drink the amino acid formula. Despite a median energy intake that exceeded the EAR it was disappointing that a significant improvement in nutritional status was not quite reached on the amino acid formula. This could be related to the slower absorption of amino acids compared with the peptides from the hydrolysed protein formula. ${ }^{7}$

Two subjects probably developed allergic colitis on the HW formula but no adverse reactions were observed with the AA formula. There is a growing concern over the use of hydrolysed protein formula for cows' milk protein intolerance as there are now several recent case reports of anaphylactic reactions to both casein and whey hydrolysates in humans. ${ }^{2} 1819$ Buscino et $a l^{20}$ reported anaphylaxis in as many as five infants following the use of a whey hydrolysate formula (Alfare; Nestlé). Patients improved on either an amino acid or a meat based formula. Ellis et $a l^{21}$ reported projectile vomiting, urticaria, rhinorrhoea, wheezing, and cyanosis in an 8 month old infant following ingestion of $15 \mathrm{ml}$ of a partially hydrolysed whey formula (Good Start; Carnation).

Hydrolysed casein infant formulas such as Nutramigen and Pregestimil (Mead Johnson) have been widely used in milk-sensitive children and have been assumed to be hypoallergenic'. Protein hydrolysates are the result of heat treatment and/or enzymatic cleavage in order to produce peptides of minor allergenic activity. ${ }^{22}$ However, as noted by the American Academy of Pediatrics, there are no published, well controlled double blind studies to support the use of either casein or whey hydrolysates for the treatment of infants with cows' milk sensitivity. ${ }^{23}$ It is possible that intolerances to these formula have been under reported in the past in patients with severe cows' milk protein intolerance.

The size of the peptides in hydrolysed formula may be important in determining its overall allergenicity. A formula containing peptides of molecular weights of less than 1200 daltons is considered to be less allergenic ${ }^{24}$ since allergic responses, including anaphylactic shock, occur in laboratory animals in response to peptides with molecular weights of 1300 or greater. ${ }^{24}$ The WH formula studied had a mean peptide molecular weight of 900 daltons, with $97 \%$ being less than 2000 daltons; many whey hydrolysates contain some peptides with a molecular weight of over 2000 daltons (Hudson M, personal communication). It has also been shown that some whey trypsin hydrolysate formulas contain residual immunogenic epitopes or antigenic determinants, including $\beta$ lactoglobulin, thus inducing an immunological cross reactivity between hydrolysates and cows' milk protein. ${ }^{25}$

In conclusion some improvement in weight and weight for length were reported in both formulas, but only weight for length reached significance for the whey hydrolysate formula. Two cases of probable reaction to the whey hydrolysate formula were identified, but otherwise both formulas were well tolerated by the infants. Amino acid formula may not have been popular in the past for the treatment of cows' milk sensitivity, but it may have a role in the management of atopic infants with severe 
cows' milk protein intolerance or who have already reacted to either whey or casein hydrolysate formula.

We wish to thank the surgeons at Birmingham Children's Hospital for allowing us to study their patients and Pam Johnson and her nursing staff on Ward PB2 for their invaluable help with the study. We also wish to thank Farleys for the provision of clinical trial supplies and financial support.

1 McLaughlan P, Anderson KJ, Widdowson EM, Coombs RRA. Effect of heat on anaphylactic sensitizing capacity of cows' milk, goats' milk and various infant formulae fed to guinea pigs. Arch Dis Child 1981; 56: 165-71.

2 Heyman MB, Stoker TW, Rudolph CD, Frick OL Hypersensitivity reaction in an infant fed hydrolysed lactalbumin contained in a semi-elemental formula. f Pediatr Gastroenterol Nutr 1990; 10: 253-6.

3 Dean TP, Adler BR, Ruge F, Warner JO. In vitro allergenicity of cows' milk substitutes. Clin Exp Allergy 1993; 23: 205-10.

4 Boner AL, Benedetti M, Spezca E, Piacentini GL, Bellanti JA. Evaluation of the allergenicity of infant formulas in a guinea pig model. Ann Allergy 1992; 68: 404-6.

5 Crampton RF, Gangolli SD, Simpson P, Matthews DM. Rates of absorption by rat intestine of pancreatic Rates of absorption by rat intestine of pancreatic
hydrolysates of proteins and their corresponding amino hydrolysates of proteins and their corres

6 Keohane PP, Grimble GK, Brown B, Spiller RC, Silk DBA. Influence of protein composition and hydrolysis method of intestinal absorption of protein in man. Gut 1985; 26 : 907-13.

7 Silk DBA, Fairclough PD, Clark ML, et al. Use of a peptide rather than free amino acid nitrogen source in chemically defined "elemental" diets. F Parenter Enter Nutr 1980; 4: 548-53.

8 Goldman AS, Anderson DW, Sellers WA, et al. Milk allergy. 1. Oral challenge with milk and isolated milk proteins in allergic children. Pediatrics 1963; 32: 425-43.

9 Hamill PVV, Drizd TA, Johnson CLJ, Reed RB, Rocho AF, Moor W. Physical growth. National Center for Health Statistics Percentiles. Am $\mathcal{f}$ Clin Nutr 1979; 32: 607-29.

10 Jelliffe DB. The assessment of the nutritional status of the community. Geneva: WHO Monogram, Ser No 53, 1982

11 Holland B, Welch AA, Unwin ID, Buss DH, Paul AA,
Southgate DAT. McCance and Widdowson's "The composition of foods", 5th ed. Cambridge: Royal Society of Chemistry/Ministry of Agriculture, Fisheries and Food 1991. 12 Department of Health. Dietary reference values for food energy
and nutrients for the UK. Report on health and social subjects No 41. London: HMSO, 1991.

13 Department of Health and Social Security. Artificial feeds for the young infant. Report on health and social subjects No 18. London: HMSO, 1980.

14 Taylor CJ, Jenkins P, Manning D. Evaluation of a peptide formula (milk) in the management of infants with multiple formula (milk) in the management of infants

15 Walker-Smith, Digeon B, Phillips AD. Evaluation of a casein and a whey hydrolysate for treatment of cows' milksensitive enteropathy, Eur F Pediatr 1989; 149: 68-71.

16 Sampson HA, James JM, Bernhisel-Broadbent J. Safety of an amino acid-derived infant formula in children allergic to cows' milk. Pediatrics 1992; 90: 463-5.

17 Vandenplas $\mathrm{Y}$, Hauser B, Blecker U, et al. The nutritional value of a whey hydrolysate formula compared with a whey-predominant formula in healthy infants. $\mathcal{f}$ Pediat Gastroenterol Nutr 1993; 17: 92-6.

18 Saylor JD, Bahna SL. Anaphylaxis to casein hydrolysate formula. F Pediatr 1991; 118: 71-4

19 Lifschitz CH, Hawkins HK, Guerra C, Byrd N. Anaphylactic shock due to cows' milk protein hypersensitivity in a breast-fed infant. $\mathcal{F}$ Pediatr Gastroenterol Nutr 1988; 7: 141-4.

20 Buscino L Cantani A Longhi MA Giampietr PG. Anaphylactic reactions to a cows' milk whey hydrolysate (Alfare, Nestles) in infants with cows' milk allergy. (Alfare, Nestles) in infants

21 Ellis MH, Short JA, Heiner DC. Anaphylaxis after ingestion of a recently introduced hydrolyzed whey protein formula. F Pediatr 1991; 118: 74-7.

22 Rugo E, Wahl R, Wahn U. How allergenic are hypoallergenic infant formulae? Clin Exp Allergy 1992; 22: 635-9.

23 Committee on Nutrition. American Academy of Pediatrics. Hypoallergenic infant formulas. Pediatrics 1989; 83: 1069-70.

24 Knights RJ. Processing and evaluation antigenicity of protein hydrolysates. In: Lifshitz F, ed. Nutrition for special needs in infancy - protein hydrolysates. New York: Marcel Dekker, 1985.

25 Buscinco L, Cantani A Hypersensitivity reaction in an infant fed hydrolysed lactalbumin. $\mathcal{F}$ Pediatr Gastroenterol Nutr 1991; 13: 429-31. 